\section{RESEARCH AND DEVELOPMENT IN THE BRITISH COLONIES}

$\mathrm{U}^{\mathrm{N}}$ NDER the title "Colonial Research 1944-45"*, there have now been issued the second annual reports of the Colonial Research Committeo and of the Colonial Products Research Council, and the first annual report of the Colonial Social Science Research Council ; for convenient record, these reports will in future be published in a single volume. Following on the reports of the Commissions on Higher Education in the Colonies and in West Africa (see Nature, Sept. 27 , p. 373), they assist materially in appraising the recommendations of those Commissions in regard to Colonial research ; and although the Colonial Research Committe日's report is not concerned with fundamental principles of policy to quite the same extent as its first report, the present report is of scarcely less general interest.

With the establishment of the specialist research committees, the main work of organization in Britain for Colonial research may be said to be well advanced. The main bodies, including a forthcoming committee for Colonial agricultural, animal health and forestry research, are directly advisory to the Secretary of State, who nevertheless looks to the Colonial Research Committee for advice on general research policy, and the Committee considers that its future work lies rather in certain co-ordinating functions which only a centrally placed body can perform. It has, first, to ensure so far as possible that no important field of inquiry is overlooked because it does not fall well within the scope of one or other of the specialist bodies; and, secondly, to maintain a proper balance in the allocation of effort and funds.

The first function is comparatively simple, and the Committee instances the study of the needs of housing research, for which purpose a Colonial Housing Research Group, with Dr. I. E. Evans of the Building Research Station as chairman, was established. The Committe $\Theta$ is also proceeding to a study of the needs of zoological and botanical surveys, in so far as these fall outside the direct scope and interest of agricultural and veterinary research. Other subjects mentioned as worthy of attention are: road research, a study of the power resources of the Colonies of all kinds, potential as well as actual, and the possible application of land utilization survey techniques. In regard to the second function, while the sum of $£ 500,000$ made available for research under the Colonial Development and Welfare Act of 1940 has so far been substantially underspent, and with the Act of 1945 that provision becomes $£ 1,000,000$ a. year, the possibility of any financial limitation of Colonial research effort seems remote, since the Committee proposes to adhere to its policy of supporting only well-conceived schemes for which adequate and suitable personnel are available. Nevertheless, the end of the War will release many research workers, and the proposed research services alone may be expected to cost substantial sums, even if Colonial governments make some contribution. Moreover, plans laid and decisions taken now are likely to have a very important effect on future trends of research policy; and, discussing the choice of the precise means to be adopted, the Committee points out that

* Colonial Research 1944-45. 1. Colonial Research Committee, Second Annual Report ; 2. Colonial Products Research Council, Second Annual Report; '3. Colonial Social Science Research Council, First Annual Report. (Cmd. 6663.) Pp. 32. (London : H.M. Stationery Office, 1945.) 6d. net. even the urgent problems do not always yield most readily to a frontal assault. The key to a particular problem, or indeed to a whole complex of problems, may lie in fundamental work in some apparently quite unrelated field. In terms of Colonial needs, it may sometimes be wisest to concentrate effort in the laboratory best equipped to deal with the key problem, wherever that problem may be; and how to discern such key problems is in itself a major problem to the solution of which the Committee proposes now to address itself.

Reviewing the fields of research, the Committee endorses the recommendations of a sub-committee of the Colonial Survey and Geophysical Committee for creating a central organization designed to complete the whole of the geodetic and major framework and half of the outstanding topographical work, making the utmost use of aerial photography. The Royal Air Force is prepared to carry out the air photography on behalf of this survey as part of its peace-time specialist training. The Committee also endorses the recommendations of a Committee on Colonial Geology for a central organization on similar lines, and the two sets of proposals provide an unrivalled opportunity of supplying the Colonies with a thorough and accurate basic knowledge of their most important resources. The Committee has also recommended a capital grant towards the cost of the fisheries research station boing installed in Mauritius, as well as the acceptance of the proposals of the Colonial Fisheries Advisory Committee for the formation of a Colonial fisheries service, to be recruited on terms of service analogous to, and interchangeable with, the federated superannuation system for universities.

The Committee considered a full report from an ad hoc sub-committee of the Colonial Advisory Council of Agriculture, Animal Health and Forestry, and supports its recommendation for the establishment of a separate committee of specialists to advise on research in these fields and to take over such functions from the Council itself. This recommendation has been accepted by the Secretary of State. A second recommendation, that in the Colonies themselves research should be organized on a regional rather than a territorial basis, has been commended to Colonial Governments, and a third recommendation for the establishment of a separate research service on the lines proposed for the fisheries service has been deferred for consideration by the new Committeo. Schemes were also made for continuing the low-temperature research station at the Imperial College of Tropical Agriculture, for research on animal diseases in the Bechuanaland Protectorate, and for a survey of animal diseases in Zanzibar.

No specific schemes for medical research involving substantial expenditure were before the Committee during the year, but schemes were made for continuing studies on the bionomies of Anopheles gambioe in Sierra Leone and Nigeria, and for D.D.T. field trials, for which $£ 4,500$ was provided. The latter scheme points the way to what may become a major development in tropical preventive medicine; workers in Africa, advised and guided by Prof. P. A. Buxton, have shown that D.D.T. is toxic to the tsetse fly. Important trials designed to work out effective techniques for its application in the field have been planned. The Committee has also recommended the adoption of an important scheme for research and development work on growing cinchona in the Colonial Empire, based in East Africa; in regard 
to medical research in general, the Committee considers that, so far as central organization is concerned, the way is now clear for a rapid and systematic attack on the major medical problems of the Colonies. It is pointed out, however, that research cannot be prosecuted effectively in this or in any other field without a regular flow of skilled men of science, and, unless energetic steps are taken, one of the chief shortages is likely to be in the field of entomology.

Other special committees established are the Tsetse Fly and Trypanosomiasis Committee and the Cocoa Research Committee, while with the aid of a grant of $£ 28,000$ now made on the recommendation of the Committee, it is intended to place the Anti-Locust Research Centre on a more permanent and satisfactory basis. Under the direction of an advisory scientific committee, the Centre will carry out a development programme covering the collection and dissemination of information (in closo collaboration with the Imperial Institute of Entomology), research and technical advice in the conduct of specific campaigns. Proposals for continuing and extending the work of the Discovery Committee, which has done magnificent work on the oceanography and marine biology of the southern seas, were also considered. A list of schemes recommended and finally approved during April 1, 1944-March 31, 1945 is appended.

The report of the Colonial Products Research Council refers to the visit of Sir Robert Robinson and Prof. J. L. Simonsen, the director of research, to the West Indies; they were accompanied on most of their tour by Dr. A. King, head of the British Commonwealth Scientific Office in Washington. Further insight into American methods of industrial development was obtained during visits to Puerto Rico and St. Thomas, and during a visit to Trinidad a detailed programme of research was worked out with Trinidad Leaseholds, Ltd., while it was suggested to the directors of the British West Indies Sugar Association (Inc.) that the formation of an industrial research organization for sugar technology might be of great value. In a visit to British Guiana, it was suggested that difficulties being encountered in schemes for agricultural development owing to the high incidence of malaria in the coastal strip offer an ideal opportunity for an experiment on the use of D.D.T., and according to preliminary reports the experiment has met with a measure of success. Correspondents with the director of research have been appointed in all the Colonies of the Caribbean. A major development during the year was the decision of the Council to open a Microbiologicat Research Laboratory in Trinidad; Dr. A. C. Thaysen has been seconded to work under the Council and direct the research of this new laboratory, which it is anticipated will provide a centre for fundamental mierobiological research in the tropies.

Reviewing research work in progress, the report refers to the investigation of expressed lime oil, which has been shown to contain limettin, isopimpinellin, bergaptol and 5-geranoxy-7-methoxycoumarin, and these crystalline constituents are now being examined as antioxidants. Work on the reactions of eugenol and its derivatives from clove oil has been actively pursued, and at the Chemical Research Laboratory of the Department of Scientific and Industrial Research Dr. L. P. Walls has studied the most suitable methods for determining the ergosterol content of yeasts and for its extraction. Work on the utilization of sucrose has been actively pursued under the direction of Prof. W. N. Haworth and Dr. L. F.
Wiggins, attention boing directed mainly to lævulinic acid, hydroxymethylfurfuraldehyde, and to the dianhydrides of mannitol and sorbitol. A large number of new substances prepared appear likely to find application as chemotherapeutic agents or in the plastics industry. Work has also been commenced in the starch field, while in that of theobromine some attention has been given to the reaction of chlorotheobromine with diamines as a route to high polymers and to a process for reducing the theobromine content of cocoa meal to about $0 \cdot 1$ per cent by solvent extraction after treatment with ammonia. The utilization of Wallaba wood resin and the study of vegetable oils from Colonial sources have also recoived attention, and a list of some important plants found in the Colonies which are likely to have medicinal or insecticidal interest is undergoing final revision.

The Colonial Social Science Research Council, which was constituted in June 1944, held eight meetings during the period to March 31, 1945, covered by its first report. The general functions of the Council comprise broadly the review of the organization of research in the social sciences in the Colonies, the scrutiny of research projects submitted to it, the making of recommendations as to the publication of the results of research and the initiation of research in fields not otherwise covered. The Council was constituted to represent the main branches of the social sciences; but economic research is eovered by the Research Sub-Committee of the Colonial Economic Advisory Committee, the chairman of that Sub-Committee being a member of the Council.

Attention is directed in the report to the need for certain types of basic data as being fundamental to many of the inquiries with which the Council is concerned, for example, the provision of sound demographic data, including census and vital statistics.

Further, the great bulk of the material required for effective study of the form and operation of political and administrative institutions consists of records in official archives, which at present are not always readily accessible without interfering with administrative work. The Council has also devoted much consideration to the attempt to ascertain what are the main research problems in the various fields, and what order of priority should be attached to them. While a comprehensive research programme has not yet been formulated, several problems have been recognized as major research needs. There is urgent need, for example, for surveys of social and economic conditions in urban and in rural areas; for comparative studies of local government; for studies of the social and economic effects of migratory labour in Africa, of land tenure in relation to agriculture and social structure, of Colonial administrative law, particularly in respect of procedure in native courts, of political development in 'plural' communities ; and for sample surveys of literacy in relation to programmes of mass education. A wide range of intensive research on individual languages and cultures of many Colonial peoples is also required.

Attention has also been given to the organization of research. For some time to come, much research in the social sciences in the Colonies must be undertaken by individual workers; but the Council realizes the value of the more integrated organization provided by local or regional institutions specifically adapted for research into social problems, and believes that more institutes such as the Rhodes. Livingstone Institute and the Sociological Department 
of the West African Institute of Industries, Arts and Social Sciences will be necessary. The Council has also in mind the need for close integration, first with the practical knowledge and requirements of governments as expressed in development and welfare programmes, and in the work of administrative officers and officers of the specialist services, and secondly, with the research programmes of other organizations in the same field. Reference is made, however, to the present extreme shortage of senior research workers fitted for independent and responsible investigation in these fields; the Council considers that for some time to come it will be necessary to draw most of the workers required from Britain. To enable any comprehensive programme of social research to be undertaken, postgraduate training of research workers on a long-term basis will be necessary, presumably at the universities; but in the present emergency the Council contemplates the provision of short-term training, appropriately planned with the ultimate objectives in mind and financed under the research section of the Colonial Development and Welfare Act. Reference is also made to the real problem which the future career of the research worker may offer, and the scarcity of openings when the investigator has completed his specific project.

Of specific research projects examined by the Council, reference may be made to work on the handbook of African languages, the ethnographic survey in Africa, research work on economic and social aspects of Colonial policy during the war period and Dr. R. R. Kuczynski's "Demographic Survey of the British Colonial Empire".

\section{INDIAN FISHES AND FISHERIES}

$\mathrm{D}$ R. SUNDER LAL HORA has added much, and is still adding, to our knowledge of the fishes of India. In a series of papers published during 1942 onwards, sometimes in association with other authors, he has dealt with a variety of subjects.

Discussing the respiratory movements of some Homalopterid fishes ${ }^{1}$, attention is directed to the close parallelism between the accessory respiratory chambers of these and the bucco-pharyngeal chambers of certain air-breathing fishes. The fishes of Poona ${ }^{2}$, with their Hindi names and distribution ${ }^{3}$, and the fishes of Mysore and adjoining hill ranges are listed. Notes on fishes in the Indian Museum ${ }^{5}$ and descriptions of the large-scaled barbels, already discussed in six previous articles, are continued ${ }^{\mathbf{4}, 6,7}$.

In May 1942, Dr. Hora was appointed to the post of director of fisheries, Bengal. One of his first activities in this capacity was a thorough investigation into the pollution of streams by the effluent of the quinine factory at Mungpo and its effect on the fish. The report ${ }^{8}$ deals with many aspects of the problem, the main conclusion being that the effluent leads to the pollution of the streams affected by it (in the sense that the stream waters do not remain natural) not so much through the chemical waste products contained in it, but by the deposition of bark residues in the form of a coloured flocculent matter of very fine consistency, and by the oil contained in the effluent. Although there may be seasonal depopulation of the streams due to pollution, the fish are not permanently injured and their breeding is not affected. The main recommendations for improvement are, so far as practicable, to remove the bark residues by sedimentation in settling tanks and possibly to recover more oil by skimming the tanks. With the construction of these tanks it may be possible to let out the effluent over a longer period, so that only a small quantity passes through the stream at a time.

Dr. Hora is always an advocate for research in all its aspects, and three of his papers $9,10,11$ show the great need for biological stations in India and above all urge the plea for the establishment of a fishery research institute. In post-war reconstruction a central organization to deal with the fisheries of the country is the obvious solution.

${ }^{1}$ J. Roy. Asiatic Soc. Bengal, Seience, 8, Art. No. 4 (1942).

${ }^{2} J$. Bombay Nat. Hist. Soc., 43, No. 1 and No. 2 (April and August, 1942).

${ }^{3}$ Rec. Ind. Mus., 44, Pt. 2 (1942)

4 J. Bombay Nat. Hist. Soc., 42, No. 2 (1942).

${ }^{5}$ Rec. Ind. Mus., 44, Pt. 1 (1942)

- J. Bombay Nat. Hist. Soc., 44, No. 1 (1943).

${ }^{7}$ J. Bombay Nat. Hist. Soc., 44, No. 2 (1943).

8 Proc. Nat. Inst. Sci. India, 10, No. 1 (1944).

- Proc. Nat. Inst. Sci. India, 10, No. 1 (1944).

${ }^{10}$ Proc. Nat. Inst. Sci. India, 10, No. 1 (1944)

${ }^{11}$ Curr. Sci. (April 1944).

\section{CHEMISTRY IN CHINA}

\section{$\mathrm{T}$} HE four volumes of the Journal of the Chinese Chemical Society ${ }^{1}$ covering the years $1941-44$ contain more than a hundred papers on all branches of the science. Many of the papers deal with problems of nutrition, vitamin content of food, fertilizers and soil types in China, and the analysis of Chinese drugs. There are investigations of the properties of vegetable gasoline made from native materials, cracking of vegetable oils, and the oxidation of natural fats and oils. The indican content of Szechwan indigo, the fixation of Chinese valonia by hide powder, and similar problems have been studied.

A large number of papers are of general chemical interest, as distinguished from those concerned with national requirements, and a very good balance is preserved between the various branches of investigation. In organic chemistry, the papers on aminoacids, the synthesis of products from ethyl alcohol, acetaldehyde from acetylene, ketones, the santonin series, enzymes and sulphanilamide derivates, may be mentioned. Several papers on analytical chemistry, including the use of the polarograph, are of interest. In physical chemistry, the papers are mostly theoretical, dealing with such subjects as ionic volumes, radii and entropies, apparent heat capacities of salts in solution, ionic polarization and refraction, electronegativity and atomic number, visccsity and eritical data. Several interesting new equations are proposed relating to these magnitudes. A paper on the temperature of maximum density of heavy water fixes this at $11 \cdot 21^{\circ}$, in good agreement with other recent investigations. There are some papers on chemical kinetics (iodine monochloride addition and unsaturated acids) and optical rotation.

The standard of the papers is high, and the record of work, some at least of which must have been carried out in difficult circumstances, is impressive. The future contributions of China to chemistry should be of great value if the present rate of progress is continued.

1 Published by the Society. Annual subscription per volume, 4 U.S. dollars. Inquiries to Dr. F. H. Lee, College of Science, University of Nanking, Chengtu, China. 